Acta Botanica Brasilica - 35(3): 491-494. July-September 2021.

\title{
Mutation in focus: first record of a wild chimeric individual for the subtribe Laeliinae (Orchidaceae)
}

\author{
Felipe Fajardo Villela Antolin Barberena ${ }^{1,2 *}$ (1)
}

Received: September 17, 2020

Accepted: January 25, 2021

\begin{abstract}
Variegated species are highly appreciated for their unique aesthetics. Although often confused, variegation and chimerism are distinct phenomena. Chimerism can also cause variation in the color of plant organs, but it is a specific type of genetic mosaic. Limited information is available on variegation and chimerism in Orchidaceae. Here, the first record of a wild foliar chimeric mutant for the subtribe Laeliinae (Orchidaceae) is presented. In July 2020, a sterile chimeric individual of Epidendrum cinnabarinum was found and photographed in a fragment of restinga in the Área de Proteção Ambiental das Lagoas e Dunas do Abaeté, a conservation unit in the municipality of Salvador in the state of Bahia, Northeast Brazil. The plant's phenotype is a mosaic of green, cream and yellow striped leaves in different proportions. Leaves on one caulome are distinctly colored, not only on the margins, but also in the central portion. Anatomical and ecophysiological aspects of the chimeric specimen need to be studied. The abundance and persistence of the chimeric variegation in the individual will be monitored while this phenomenon should be more closely examined for the species.
\end{abstract}

Keywords: conservation, foliage plants, Epidendrum, Epidendrum cinnabarinum, morphology, Neotropical, orchids, phenotype, restinga, variegation

Variegation in plants is mainly characterized by markings of different colors on leaves or petals, manifested as stripes, blotches and streaks, that are often located on the margins (Marcotrigiano 1997). It can be caused by nutritional disorders, pest damage, differential gene expression, leaf blisters, viruses or genetic mosaicism (Marcotrigiano 1997). Species with variegated foliage are extremely appreciated by plant lovers and growers due to their peculiar morphology and unique aesthetics, and thus are of considerable economic value in the ornamental plant market (Behe et al. 1999; Valverde et al. 2012).

1 Herbário do Campus Capitão Poço, Universidade Federal Rural da Amazônia, 68650-000, Capitão Poço, PA, Brazil

2 Coordenação de Botânica, Museu Paraense Emílio Goeldi, 66077-830, Belém, PA, Brazil

*Corresponding author: felipe.fajardo@ufra.edu.br 
Foliar variegation is common in certain botanical families such as Araceae, Araliaceae, Asparagaceae, Bromeliaceae, Euphorbiaceae and Myrsinaceae (Li et al. 2007; Khalekuzzaman et al. 2015), but relatively uncommon in Orchidaceae.

Some terrestrial orchids of the subfamily Orchidoideae have leaves that are green to variously splashed, blotched, lined or tinged with white or silver, such as species of Cyclopogon C.Presl and Mesadenella Schltr., or commonly with white and well-demarcated reticulated nerves, as seen in Aspidogyne Garay, Goodyera R.Br. and Ludisia A.Rich. However, variegated patterns are not exclusive to the subfamily Orchidoideae. Species of Paphiopedilum Pfitzer (Cypripedioideae) and Oeceoclades maculata (Lindl.) Lindl. (Epidendroideae) are other examples of bi-colored terrestrial orchids with green foliage with lighter green blotches. Furthermore, on the internet, it is possible to find photos of other variegated individuals of highly commercial genera of the subfamily Epidendroideae, such as Dendrobium Sw. and Phalaenopsis Blume, and even of less exuberant genera, such as Epidendrum L. and Encyclia Hook (e.g., Giulio Celandroni Orchidee 2020; Orchidéhuset 2020; Vintage Green Farms 2020). These individuals are mainly hybrids and have cream or yellow bands at the edges of the leaves and are especially rare (Mursyanti et al. 2016; Vintage Green Farms 2020). Variegated individuals of mini Phalaenopsis have been produced commercially, but less than $0.01 \%$ of the plantlets derived from seeds from self-pollinated variegated plants exhibited a variegated pattern (Mursyanti et al. 2016).

Variegation and chimerism are often inseparable and confused, but they are distinct phenomena (Marcotrigiano 1997; Prina et al. 2012). Chimerism also causes variation in the color of plant organs, but it is a specific type of genetic mosaic; chimeric individuals have genetic differences in one or more layers of the apical meristem, and are classified as periclinal, mericlinal or sectorial chimeras based on the arrangement of the genetically dissimilar cells (Marcotrigiano 1997). Chimeras may be the result of genetic changes in the nuclear or chloroplast genome (spontaneous or induced), transposition of genetic elements, synthesis of graft chimeras, semigamy or tissue culture synthesis of chimeric meristems (Marcotrigiano 1997). Chimeras are frequently studied with regard to ontogenesis and have potential to be employed in the genetic improvement of cultivars (Bomfim 2014). Nonetheless, there is no information available about chimerism in Orchidaceae.

Laeliinae is probable the most ornamental subtribe of the family Orchidaceae, comprising ca. 2,100 species, in addition to thousands of hybrids, mainly artificial, with Epidendrum being its largest genus (Withner 1988; van den Berg 2008; Chase et al. 2015). Although numerous species of Epidendrum have been described, mainly in the past two decades and at a rate of roughly 25 per year (Barberena \& Gonzaga 2016), there is no mention of collected specimens or individuals photographed in nature having leaves lined or tinged with white, cream or yellow.
Species of Epidendrum always have green to purple leaves (Pridgeon et al. 2005), but this variation in coloration is apparently associated with sun exposure (greater or lesser UV radiation) interfering with the synthesis of anthocyanins, as reported for some species of Bromeliaceae by Benzing \& Friedman (1981). Similarly, I am unaware of any record in the literature regarding foliage with lighter non-green margins for other genera of Laeliinae.

Therefore, presented here is what can be considered the first record in the wild of an individual of the subtribe Laeliinae (Orchidaceae) with foliar chimerism. In July 2020, one sterile chimeric individual of Epidendrum cinnabarinum Salzm. was found and photographed in a fragment of restinga in the municipality of Salvador in the state of Bahia, Northeast Brazil.

The registered specimen is a well-developed terrestrial individual with two caulomes and two keikis. The phenotype is a mosaic of green, cream and yellow striped leaves in different proportions. Leaves on one caulome are distinctly colored, not only the margins, but also the central portion, ranging almost from one end of the color spectrum to the other, sometimes with striking to smooth cream or yellow stripes and sometimes almost totally green (Fig. 1A-D). Apparently, the chimeric individual does not differ morphologically from totally green individuals (Fig. 2); the leaves of the chimeric individual are regular in shape and texture, being coriaceous and predominantly oblong. Although measurements of vegetative parts have not been taken, it is almost certain that the chimeric individual has dimensions within those observed for the species.

Epidendrum cinnabarinum is restricted to Northeast Brazil, where it occurs from the state of Rio Grande do Norte to the state of Bahia (Pessoa 2020). It is particularly well distributed along the coast of Bahia state and forms a relatively large population (more than 150 individuals) in Área de Proteção Ambiental das Lagoas e Dunas do Abaeté (APA Abaeté) (Barberena et al. 2019), the conservation unit where the chimerical individual was found. The APA Abaeté consists of a vegetational mosaic with herbaceous, shrub and tree phytophysiognomies surrounded by partially urbanized to predominantly urbanized areas. The individual was found in a non-floodable shrub formation in one of the most preserved localities of APA Abaeté, which has regular surveillance carried out by the employees of Parque Municipal das Dunas, which is part of APA Abaeté (Diário Oficial do Município de Salvador 2011; Barberena et al. 2019).

The difference in color between green leaves and chimeric leaves are notorious (Figs. 1A-D, 2) and thus chimeric individuals are easily recognized by their inconsistent color pattern even on the same caulome. The individual reported and photographed here is a chimera since foliar chimerism is clear cut and expressed as elongated stripes in monocots (Prina et al. 2012). Further, chimerism is recognized mainly by most of the adventitious shoots sorting into component genotypes, the occasional appearance of nonvariegated shoots and the 


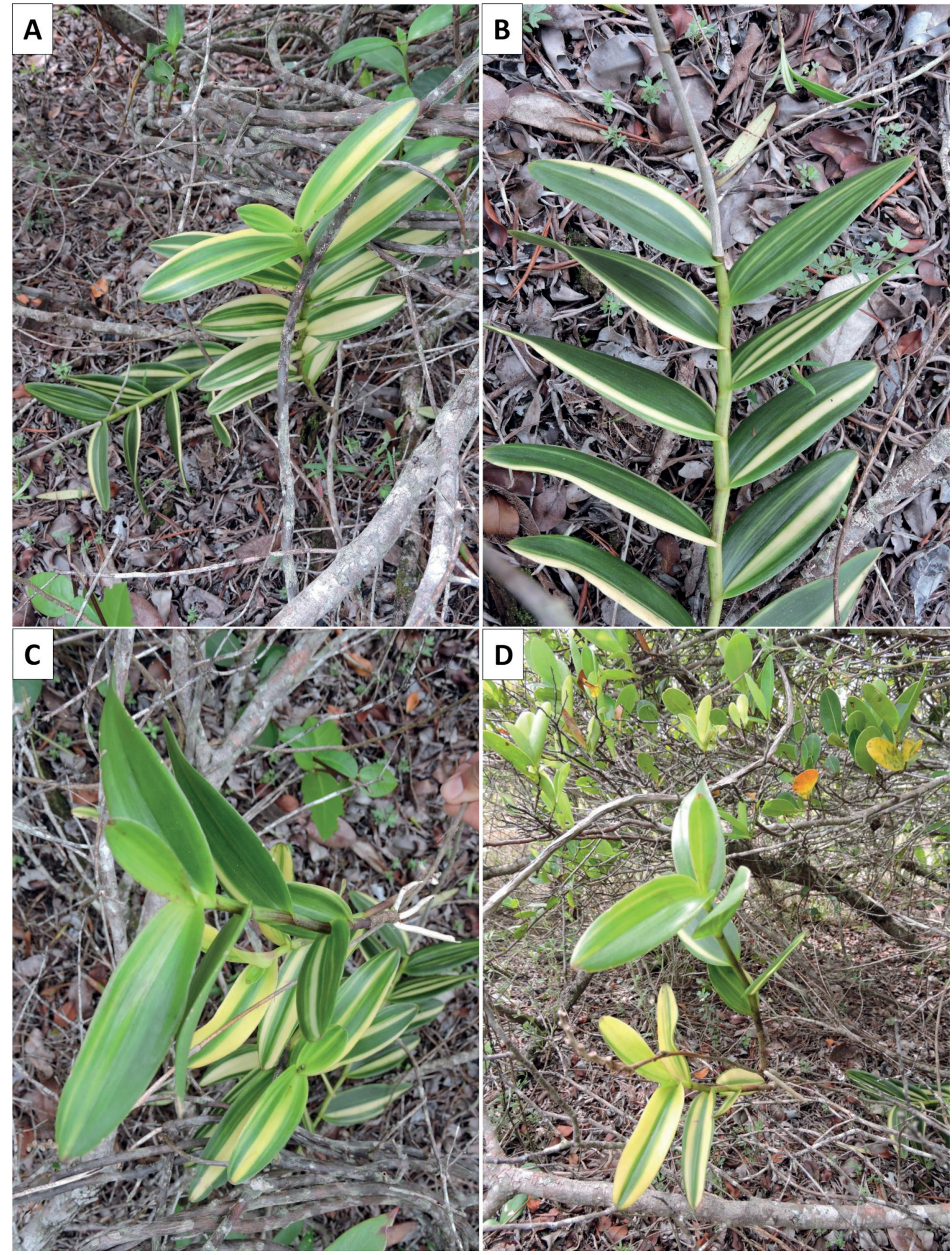

Figure 1. Chimeric individual of Epidendrum cinnabarinum Salzm. in Área de Proteção Ambiental das Lagoas e Dunas do Abaeté, Bahia, Brazil, showing an inconsistent color pattern of the leaves with green, cream and yellow striped leaves in different proportions even on the same caulome. Photographed by Felipe Fajardo V. A. Barberena. 
lack of a relevant variegated phenotype in wild populations (Marcotrigiano 1997). All of these characteristics could be observed or related to the present case. The hypothesis of virus infection is ruled out since viruses in orchids often promote asymptomatic infections; when infections are symptomatic, they are mainly expressed by leaves with chlorotic or necrotic spots, which may be depressed or not and are irregularly distributed (Kubo et al. 2009; Kitajima et al. 2010; Moraes et al. 2017). In any event, infected plants do not display distinct cream or yellow and longitudinal stripes on the leaves.

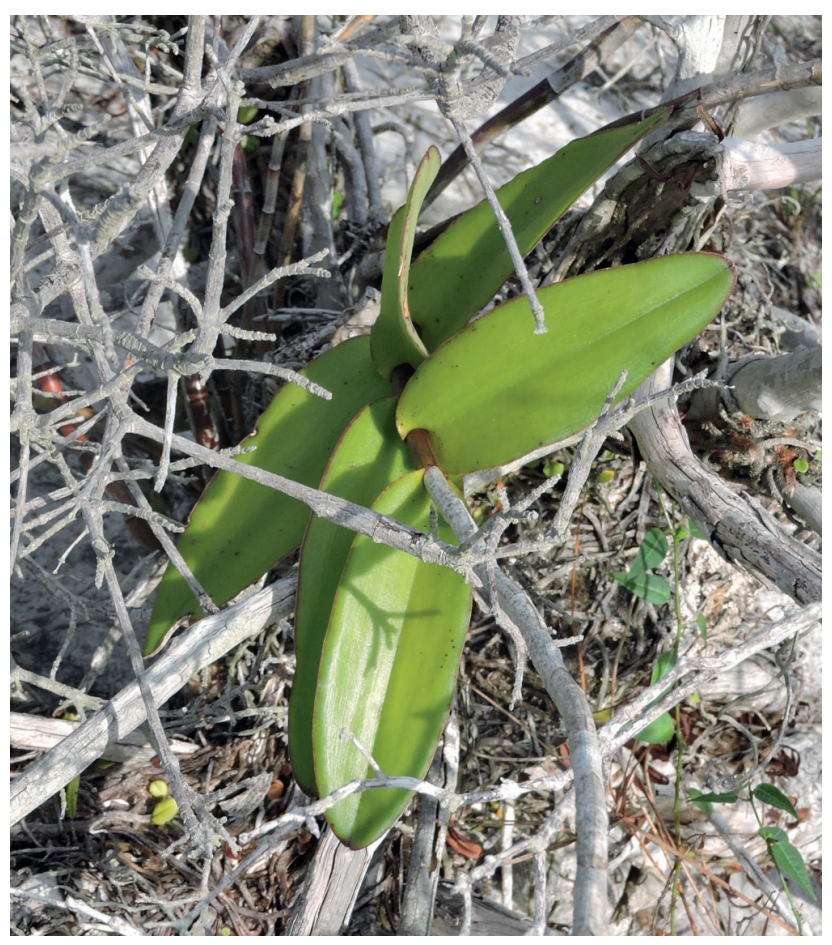

Figure 2. Individual of Epidendrum cinnabarinum Salzm. in Área de Proteção Ambiental das Lagoas e Dunas do Abaeté, Bahia, Brazil, showing the typical totally green foliage of the species. Photographed by Felipe Fajardo V. A. Barberena.

The chimeric mutant of E. cinnabarinum could be used as a parental plant for horticultural breeding, but anatomical and ecophysiological aspects of the chimeric specimen would need to be studied first. Nonetheless, the immediate goal agreed to with the park manager is the ex situ cultivation of the individual in a greenhouse. The abundance and persistence of the phenotypic mosaic of the individual will be monitored while this phenomenon should be more closely examined for the species.

\section{Acknowledgements}

I thank Mr. Jorge Santana, manager of Parque Municipal das Dunas, for allowing access to the area; and Erik Wild, for reviewing English.

\section{References}

Barberena FFVA, Gonzaga DR. 2016. A new species of Epidendrum (Epidendroideae; Orchidaceae) from the Brazilian Atlantic Forest. Phytotaxa 284: 225-230.

Barberena FFVA, Sousa TS, Rocha Junior JAL. 2019. Mapping threats to the orchid populations in an environmental protection area in Bahia, Northeast Brazil. Oecologia Australis 23: 346-356.

Behe B, Nelson R, Barton S, Hall C, Safley CD, Turner S. 1999. Consumer preferences for geranium flower color, leaf variegation, and price. Hortscience 34: 740-742.

Benzing DH, Friedman WE. 1981. Patterns of foliar pigmentation in Bromeliaceae and their adaptive significance. Selbyana 5: 224-240.

Bomfim NN. 2014. Quimeras periclinais em Manihot: sua síntese, identificação e potencial econômico. $\mathrm{PhD}$ Thesis, Universidade de Brasília, Brasília.

Chase MW, Cameron KM, Freudenstein JV, et al. 2015. An updated classification of Orchidaceae. Botanical Journal of the Linnean Society 177: 151-174.

Diário Oficial do Município de Salvador. 2011. Decreto n ${ }^{\circ} 22.507$, de 22 de dezembro de 2011. https://leismunicipais.com.br/a/ba/s/salvador/ decreto/2011/2250/22507/decreton-22507-2011-delimita-eimplanta-o-parquedas-dunas-amplia-o-parque-do-abaete-e-daoutrasprovidencias. 27 Aug. 2020.

Giulio Celandroni Orchidee. 2020. Phalaenopsis Sogo Vivien 'SOGO F858' (variegata). https://www.celaorchidee.it/shop/ibride/phalaenopsisibride/phalaenopsis-sogo-vivien-sogo-f858-variegata/. 23 Nov. 2020.

Khalekuzzaman MD, Kim KJ, Kim JH, Jung HH, Jang HS. 2015. Comparison of green and variegated foliage plant species based on chlorophyll fluorescence parameters under different light intensities. Pakistan Journal of Botany 47: 1709-1715.

Kitajima EW, Rodrigues JCV, Freitas-Astua J. 2010. An annotated list of ornamentals naturally found infected by Brevipalpus mite-transmitted viruses. Scientia Agricola 67: 348-371.

Kubo KS, Freitas-Astua J, Machado MA, Kitajima EW. 2009. Orchid fleck symptoms may be caused naturally by two different viruses transmitted by Brevipalpus. Journal of General Plant Pathology 75: 250-255.

Li Q, Chen J, McConnell DB, Henny RJ. 2007. A simple and effective method for quantifying leaf variegation. HortTechnology 17: 285-288.

Marcotrigiano M. 1997. Chimeras and variegation: patterns of deceit. HortScience 32: 773-784.

Moraes LA, Krause-Sakate R, Pavan MA. 2017. Incidence and characterization of viruses infecting orchids in São Paulo state, Brazil. Tropical Plant Pathology 42: 126-131.

Mursyanti E, Purwantoro A, Moeljopawiro S, Semiarti E. 2016. Micropropagation of mini orchid hybrid Phalaenopsis "Sogo Vivien". Journal of Tropical Biodiversity and Biotechnology 1: 45-53.

Orchidéhuset. 2020. Dendrobium nobile, variegatum. https://www. orchidehuset.se/produkt/dendrobium-nobile-variegatum/. 23 Nov. 2020.

Pessoa EM. 2020. Epidendrum. In: Flora do Brasil. 2020. http://floradobrasil. jbrj.gov.br/reflora/floradobrasil/FB179/. 27 Aug. 2020.

Pridgeon AM, Cribb PJ, Chase MW, Rasmussen FN. 2005. Genera Orchidacearum. Vol. IV. New York, Oxford University Press.

Prina AR, Landau AM, Pacheco MG. 2012. Chimeras and mutant gene transmission. In: Shu QY, Brian PF, Nakagawa H. (eds.) Plant mutation breeding and biotechnology. Vienna, Austria, CABI Publishing. p. 181-189.

Valverde RA, Sabanadzovic S, Hammond J. 2012. Viruses that enhance the aesthetics of some ornamental plants: beauty or beast? Plant Disease 96: 600-611.

van den Berg C. 2008. New combinations in the genus Cattleya Lindl. Neodiversity 3: 3-12.

Vintage Green Farms. 2020. Epidendrum 'variegated red'. http://tompiergrossi.squarespace.com/orchids/epidendrum-variegated-red/. 23 Nov. 2020.

Withner CL. 1988. The Cattleyas and their relatives. Vol. I. The Cattleyas. Portland, Timber Press. 